Ritstýrð grein birt 31. desember 2020

\title{
Dagleg einkunnagjöf í íslenskum skólum
}

\begin{abstract}
Helgi Skúli Kjartansson
Abstract

- Um höfund

About the author

- Heimildir

Greinin fylgir eftir rannsókn Lofts Guttormssonar (2007) á svonefndum „daglegum einkunnagjöfum “ í íslenskum barnaskólum, sérstaklega í Reykjavík, áratugina kringum 1900. Samsvarandi einkunnagjöf í Lærða skólanum í Reykjavík, sem Loftur telur beina fyrirmynd barnaskólans í pví efni, er athuguð með samanburði útgefinna heimilda við „vitnisburðarbók“ skólapilts 1885-1886. Lauslegur samanburður sýnir að framkvæmdin var svipuð í dönskum skólum og hinum íslensku, aðferðinni í báðum löndum beitt löngu eftir að hún var orðin hastarlega á skjön við viðtekna kennslufræði. Aðferðin fólst í að gefa nemanda talnaeinkunn fyrir frammistöðu sína í hverri kennslustund og hélst í hendur við „yfirheyrsluaðferð“ í kennslu, p.e. að kennari setti fyrir og hlýddi yfir án pess að eyða tíma í útskýringar eða fræðslu. Eftir einkunnum var nemendum svo skipað í „skólaröð“ sem m.a. réð sætaskipan í skólastofunni. Í Lærða skólanum var pessi aðferð nokkuð umdeild en pó beitt - með ýmsum tilslökunum, misjöfnum eftir námsgreinum - uns hún var afnumin með breytingunni í menntaskóla 1904. Í barnaskólum fjaraði hún út um svipað leyti, svo treglega pó að 1908 sá nýskipaður fræðslumálastjóri ástæðu til að mæla skörulega gegn henni.
\end{abstract}

Efnisorð: Námsmat, símat, yfirheyrsluaðferð, lærði skóli, skólaröð

\section{Vitnisburðarbók úr Lærða skólanum}

Fyrir skömmu kom upp í hendurnar á mér skólasöguleg heimild, prentað kver með eyðum til útfyllingar, gefið út í Reykjavík „á forlag Kristjáns Ó. Porgrímssonar“ 1884 og ætlað til nota í Lærða skólanum. Рað er fjórar arkir auk kápu, alls 36 blaðsíður. Í örkunum eru allar blaðsíður eins, 32 talsins, hver ætluð einni viku. Mynd 1 sýnir slíka síðu oútfyllta.

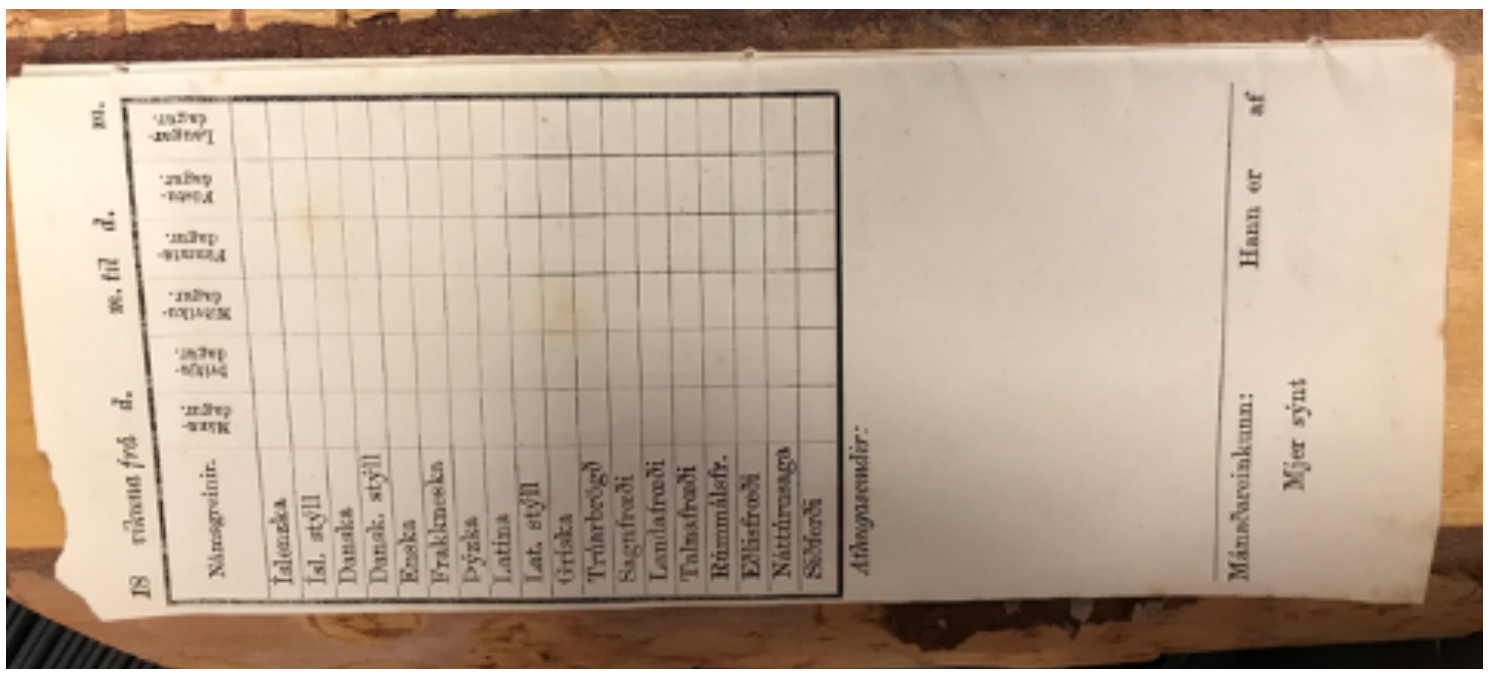

Mynd 1. Óútfyllt blaðsîða úr vitnisburðarbók skólapilts í Lærða skólanum. 
Efst er gert ráð fyrir ártali og dagsetningum. Síðan er einkunnatafla; átján línur fyrir námsgreinar skólans, sex dálkar fyrir virka daga vikunnar (mánudag til laugardags). Hér er sem sagt pláss fyrir rúmlega 100 einkunnir á viku! Auðvitað hefði aldrei komið til greina að nota töfluna alla, pó ekki væri fyrir annað en að hver námsgrein var ekki kennd alla daga vikunnar og ekki endilega öll skólaárin, en parna er pó a.m.k. svigrúm til pess fyrir hvern kennara að skrá einkunnir í hvert einasta skipti sem hann kennir. Undir einkunnatöflunni er pláss fyrir „athugasemdir“. Par fyrir neðan lína fyrir „mánaðareinkunn“ og skólaröð („Hann er ... af ...“), en pað hvort tveggja hefur aðeins átt að nota einu sinni í mánuði. Og neðst „Mjer sýnt“ með plássi fyrir undirskrift forráðamanns.

Eintakið, sem ég er með, er útfyllt á forsîðu eins og Mynd 2 sýnir.

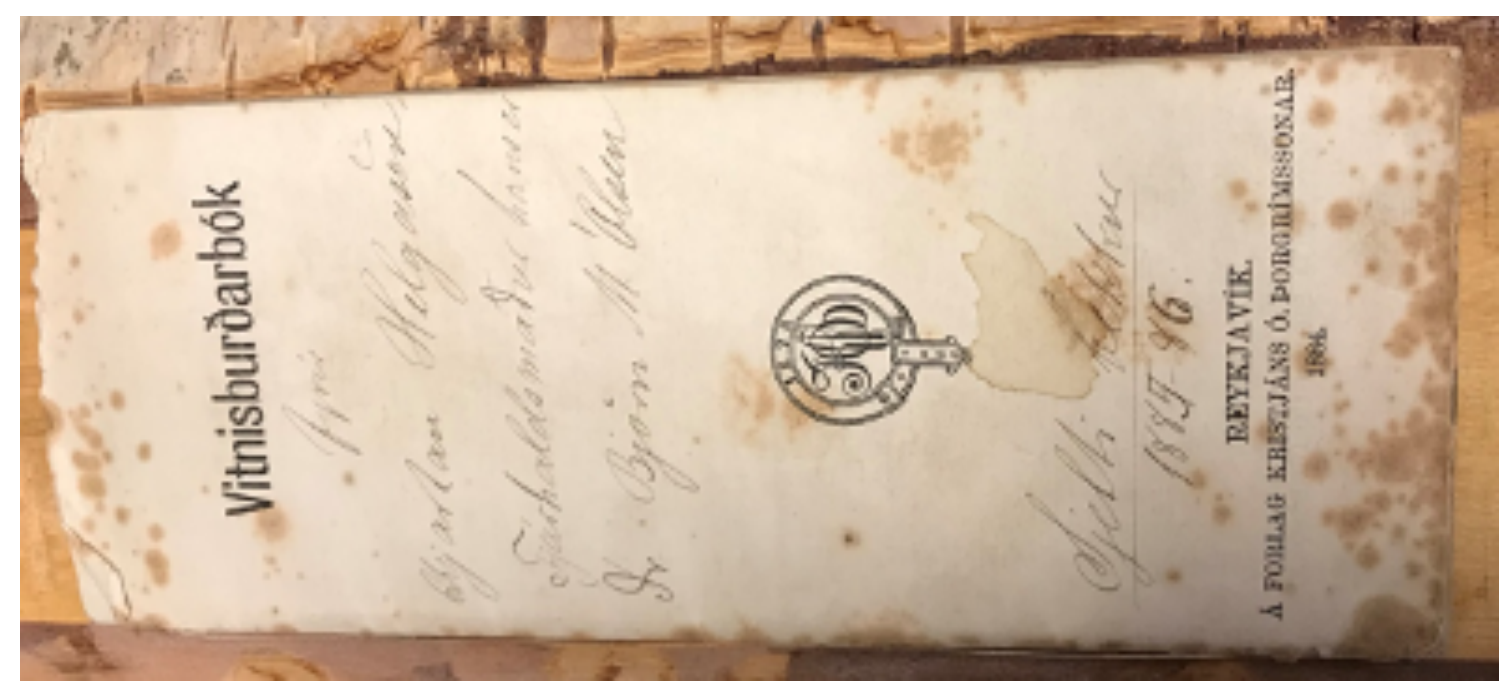

Mynd 2. Forsíða vitnisburðarbókar Kjartans Helgasonar frá Birtingaholti 1885-1886.

Petta er sem sagt „Vitnisburðarbók fyrir Kjartan Helgason“ frá Birtingaholti (síðar prest, lengst í Hruna í Árnessýslu) í „sjetta bekk“ - síðasta veturinn fyrir stúdentspróf - 1885-1886. Hann var pá, samkvæmt skólaskýrslu (Skýrsla um hinn larða skóla, 1886, bls. 30), „umsjónarmaður við bænir og kirkjugöngu“. „Fjárhaldsmaður" hans í Reykjavík er einn af kennurum skólans, Björn M. Ólsen síðar rektor.

Svo koma vikurnar. Sú fyrsta 5.-10. október, svo koll af kolli til 27. mars, alls 25 vikur, hver síða útfyllt með ártali og dagsetningum. Ekki hefur verið pörf fyrir síðustu sjö síðurnar. Samkvæmt pví virðist hafa verið priggja mánaða upplestrarfrí fyrir stúdentsprófin sem hófust ekki fyrr en 25. júní.

Af vikunum 25 eru sjö auðar fyrir utan dagsetningar. Jólafrí virðist býsna langt, pví að fimm vikur eru auðar frá 21. desember til 23. janúar. Er pá stutt í tvær yfirstrikaðar síður í febrúar sem munu tákna miðsvetrarpróf með upplestrarfríi. Kennsluvikur hafa pá verið ellefu fyrir jól og ekki nema sjö eftir jól - kennslu lokið löngu fyrir páska. Ekki kemur fram hvort kennsla hafði fallið niður eða Kjartan verið forfallaður einstaka tíma og jafnvel daga.

Hinar átján skólavikur Kjartans eru allar útfylltar með einkunnum og allar með undirskrift Björns. „Mánaðareinkunn“ er aðeins færð á tveggja mánaða fresti, í byrjun desember, febrúar og apríl. Einungis á peim sömu síðum er notað plássið fyrir „athugasemdir“ og pá til pess að tilgreina í hvaða greinum Kjartan hafi fengið ágætiseinkunn. Neikvæðar athugasemdir koma ekki fyrir. 


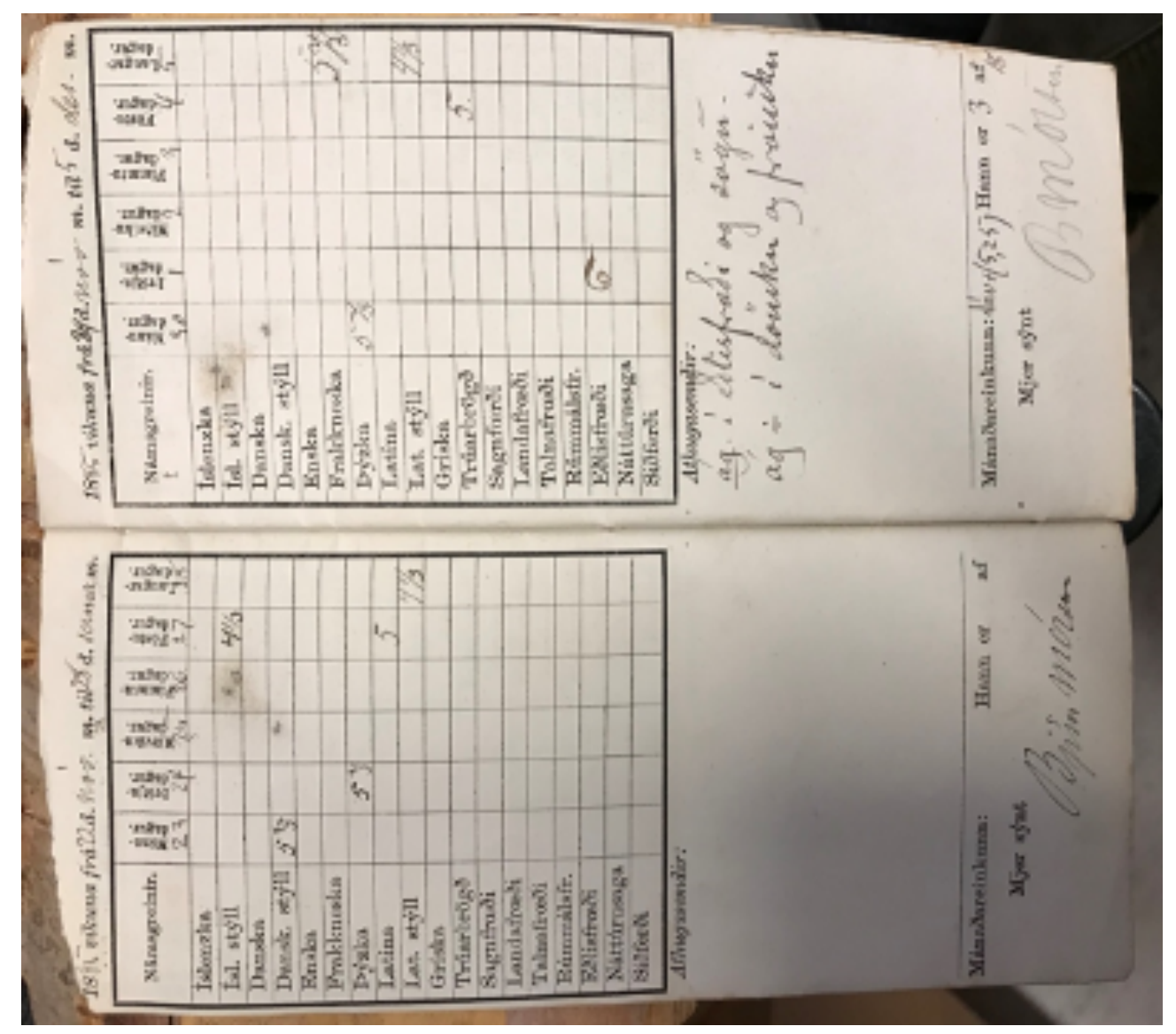

Mynd 3. Opna úr vitnisburðarbók Kjartans Helgasonar frá Birtingaholti 22. nóvember til 5. desember 1885.

Mynd 3 sýnir opnu úr vitnisburðarbókinni; vikurnar 22. nóvember til 5. desember. Hér er strjálingur af einkunnum, fimm í hvorri viku. Einkunnaskalinn nær upp í 6 , gefið í heilum og priðjungum. Hér dreifast einkunnir frá $41 / 3$ upp í 6 sem er dæmigert fyrir allan veturinn (sléttir 4 koma fyrir einu sinni í bókinni). Mánaðareinkunnin er „dável plús“ og í skólaröðinni er Kjartan priðji af átján.

\section{Takturinn í yfirheyrslum}

Einkunnir Kjartans dreifast mjög óreglulega á daga, vikur og námsgreinar. Að meðaltali fær hann sex einkunnir á viku, oftast fimm til sjö, sjaldnar átta og niður í tvær. Pær geta verið í tveimur eða premur námsgreinum sama daginn og einkunnalausir dagar í flestum vikum, iðulega tveir í röð og upp í fjóra. Forföll, annaðhvort Kjartans eða kennaranna, kynnu að skýra eitthvað af pessu einkunnaleysi, pó varla nema lítinn hluta pess.

Sérstakar línur eru í bókinni fyrir einkunnir í íslenskum, latneskum og dönskum „stíl“, sem mun vera samheiti fyrir ritgerðir og pýðingar. Önnur skrifleg verkefni er ekki getið um, og má ætla að flestar eða allar einkunnir í öðru en „stíl“ hafi Kjartan fengið fyrir frammistöðu sína pegar hann var „tekinn upp“ og yfirheyrður. Samkvæmt skólaskýrslu var í dönsku „einni stund á viku varið til stíla“, og er par greinilega átt við verkefni í tíma. Í íslensku var gerður „einn stíll á viku“án pess tekið sé fram hvort pað var heimaritgerð, en líklegra er að piltar hafi unnið í tíma undir eftirliti, líkt og á skriflegu prófi. Sömuleiðis í latínu; um latneskan stíl segir ekkert í skólaskýrslu en sjö vikustundir hafa gefið ærið svigrúm fyrir pýðingar í tíma.

Fyrir latneskan stíl fær Kjartan einkunn tólf sinnum, vikulega fyrstu fimm vikurnar, síðan með óreglulegum hléum. Einkunnin er alltaf færð á laugardögum, en vera má að kennarinn, Jón Porkelsson 
rektor, hafi tekið sér einhverja daga til að fara yfir verkefnin. Og fellt niður stílagerðina af og til, að jafnaði í priðja hvert skipti.

Aðrar tólf einkunnir fær Kjartan í latínu, örugglega fyrir frammistöðu við yfirheyrslu. Pær dreifast á aðeins fjóra vikudaga; er pví svo að sjá að tímarnir sjö hafi ekki fallið á alla kennsludaga vikunnar. Á átján vikum hefði Kjartan að forfallalausu átt að sækja 126 latínutíma, sem í raun má giska á að hafi verið 110 til 120, par af farið einn eða tveir í hvern af stílunum tólf. Eru pá eftir um eða yfir 90. Ef Kjartan var tekinn upp tólf sinnum gerir pað u.p.b. eitt skipti af hverjum átta, líkt og í átján manna bekk hafi að jafnaði verið teknir upp tveir frekar en prír í hverri kennslustund. Yfirheyrslur Jóns rektors hafa pá annaðhvort verið býsna rækilegar eða hann hefur gefið sér talsverðan tíma til annars konar kennslu meðfram.

Enn frekar á pað við um íslenskukennslu Halldórs Kr. Friðrikssonar. Hann hefur ekki gefið Kjartani einkunn fyrir stíla nema sjö sinnum á átján vikum, sem pó áttu að vera „einn á viku“. Og aðrar einkunnir ekki nema fjórar yfir veturinn, pó íslenska væri kennd prjár stundir á viku. Kjartan ætti að hafa sótt yfir 50 íslenskutíma, eða 40-50 umfram pá sem fóru í stílana, og verið tekinn upp í tíunda eða tólfta hvert skipti. Af pví að dæma hefur Halldór að jafnaði aðeins tekið upp einn pilt eða tvo í hverjum tíma og pá haft verulegt svigrúm til annars konar kennslu. Allt annað snið hefur verið á pýskukennslu hins sama Halldórs. Par voru vikustundir fimm, ekkert getið um stíla, en Kjartan fékk einkunn 16 sinnum, nánast vikulega. Eftir pví ætti Halldór að hafa yfirheyrt prjá til fjóra pilta í hverjum pýskutíma og pá varla gert mikið annað.

Dönsku stílarnir hafa ekki, fremur en peir íslensku, verið vikulegir í raun, pví fyrir pá fær Kjartan líka aðeins sjö einkunnir, péttast fyrstu vikurnar. Og aðrar dönskueinkunnir samtals ekki nema prisvar, einu sinni fyrir jól, tvisvar eftir. Dönskutímar voru pó ekki nema tveir á viku og yfirheyrslur pví, að ætla má, heldur tíðari en í íslenskunni. Sömuleiðis í grísku - fimm vikustundir og níu einkunnir - og trúarbrögðum - kennt tvo tíma á viku og Kjartan fékk fjórum sinnum einkunn.

Tíðari yfirheyrslur hafa ekki aðeins verið í pýsku heldur líka í sagnfræði (hjá Páli Melsted), par sem Kjartan kom upp níu sinnum, eðlisfræði, tíu sinnum, og frönsku, líka tíu sinnum. Hér voru vikustundir prjár í hverju fagi og einkunnafjöldinn nálægt pví að prír piltar hefðu verið yfirheyrðir í hverjum tíma.

Athygli vekur að einkunnir Kjartans dreifast býsna ójafnt, jafnvel svo að í frönsku fær hann eina vikuna tvær einkunnir, öðru sinni sögueinkunn bæði á fimmtudegi og laugardegi, og tvívegis tvær pýskueinkunnir í sömu vikunni. Sýnilega hafa kennarar gætt pess að piltar gætu ekki reiknað út hvenær röðin kæmi að peim næst.

Á öftustu síðum vitnisburðarbókarinnar (kápusîðum) eru einkunnatöflur fyrir „miðsvetrarpróf“ og „aðalpróf“. Hin sỉðari er oútfyllt hjá Kjartani, pví að hann tók í petta sinn stúdentspróf en ekki árspróf. Á miðsvetrarprófi fær hann hins vegar skráđar einkunnir í tíu greinum ásamt „aðaleinkunn dáv[el] + 5,20“ og að hann sé „3. af 18“. Mánaðareinkunnirnar prjár voru svipaðar, alltaf á bilinu „dável plús“, og skólaröðin alltaf „priðji af 18 “. Kjartan hefur pá setið í fremstu röð í skólastofunni, annar maður frá dúxinum ósigrandi, Hannesi Porsteinssyni (síðar pjóðskjalaverði), og við hlið Jóhannesar Jóhannessonar (síðar bæjarfógeta - sem brátt varð mágur Kjartans).

\section{Skyndipróf og símat}

Vitnisburðarbók Kjartans í Birtingaholti sýnir dæmi um námsmat af pví tagi sem kennt var við „daglega einkunnagjöf“ (d. daglig karaktergivning). Með pví er ekki átt við að nemandi fái einkunn á hverjum kennsludegi heldur að einkunn sé gefin í hverri námsgrein alla pá daga sem hún er kennd.

Pessi aðferð myndi á máli nútímans flokkast undir simat. Og pað í peirri öfgafengnu útfærslu að námsmatið leggur undir sig mestallt skólastarfið. Hver einasta kennslustund verður pað sem nú væri 
nefnt skyndipróf, annaðhvort skriflegt fyrir allan bekkinn eða munnlegt fyrir svo marga nemendur sem kennarinn nær að „taka upp“ og hlýða yfir.

Hin prentaða vitnisburðarbók er skipulögð fyrir strangt kerfi „daglegra einkunna“ sem pó hefur verið nokkuð sveigjanlegt í framkvæmd. Mánaðareinkunnir eru aðeins reiknaðar á tveggja mánaða fresti, „vikulegir“ stílar ekki gerðir, eða a.m.k. ekki metnir, nema aðra hverja viku, og misjafnt eftir námsgreinum hvort kennarar leggja kapp á að yfirheyra pilta sem tíðast.

\section{Allt fram á 20. öld}

Hvort pessi framkvæmd var svipuð allan starfstíma Lærða skólans (1846-1904) hef ég enga nákvæma yfirsýn yfir.

Að kennarar gæfu öllum bekknum einkunnir, líka peim sem ekki vannst tími til að yfirheyra, kann að hafa pekkst á fyrstu áratugum skólans. Matthías Jochumsson (1946, bls. 22) lýsir hvernig öldungurinn Björn Gunnlaugsson hafi um 1860 gefið „hverjum pilti 6 og svo hverjum hinna, sem sögðust hafa vitað pað sama eða vel pað." Óljósari er vitnisburður Jóns Ólafssonar (1946, bls. 29) sem hefur eftir kennara á 7. áratugnum að gáfaður nemandi gæti „fengið 6 í hverjum tíma“.

Um 1880 var í nokkur ár prófað að sleppa daglegum einkunnum í tveimur efstu bekkjunum. Var pá látið nægja að hver kennari gæfi nemendum almennt orðaða umsögn á tveggja mánaða fresti (sjá t.d. Lærisveinar hins lærða skóla, 1882). Pess getur Kristinn Daníelsson (1946, bls. 55-56), en röðun pilta eftir daglegum einkunnum hafði orðið honum til hvatningar á fyrsta skólaári hans og pví telur hann (bls. 54) „að daglegir vitnisburðir og röðun hafi verið gagnleg.“”

Petta stóð pó ekki lengi (Finnur Jónsson, 1883, bls. 124). Síðan héldust daglegar einkunnir í öllum bekkjum meðan Lærði skólinn var við lýði - við litla hrifningu nemenda. „Skólapiltar vildu, að daglegar einkunnir yrðu pegar afnumdar, en pað fékkst ekki“, segir Ásmundur Guðmundsson (1946, bls. 236) um andóf í skólanum haustið 1903.

Til samanburðar við vitnisburðarbók Kjartans Helgasonar hef ég sams konar bækur Geirs G. Zoëga úr 2. bekk 1898-1899 og 4. bekk 1900-1901. Đær sýna enga verulega kerfisbreytingu. Í staðinn fyrir vikulegt pláss fyrir „mánaðareinkunn“ eru komnir fjórir hálfsíðu reitir fyrir „sætaskipun“, en með nákvæmlega sömu upplýsingum, p.e. meðaleinkunn, skólaröð og upptalningu á ágætiseinkunnum. Fjórða röðunin er fyrir apríl og maí, mánuðina sem hjá Kjartani fóru í upplestrarfrí fyrir stúdentspróf. Hún er ekki gerð fyrr en kennslu var lokið og hefur pví litlu ráðið um raunverulega sætaskipan, nema ef vera skyldi í prófstofum við skrifleg vorpróf.

Í bókum Geirs eru miklu meiri upplýsingar um frí og forföll en hjá Kjartani. Hér má t.d. sjá frí sumardaginn fyrsta og afmælisdag konungs, mánaðarfrí „frá kl. 103\%““ og „póstfrí frá 4 á mánud. til 4 á priðjud.“, væntanlega til að piltar gætu svarað bréfum meðan landpóstar stöldruðu við í Reykjavík. Á tveggja mánaða fresti er frídagur merktur „raðað“ - p.e. fyrir kennara að reikna út skólaröðina. Vel má vera að eitthvað af einkunnalausu dögunum í vitnisburðarbók Kjartans séu líka frídagar.

Hjá Geir er jólafríið stutt, „frá kl. 111/1““ á Porláksmessu 1898, en degi fyrr 1900 pegar Porláksmessa féll á sunnudag. Kennsla hófst aftur 4. janúar 1899, en 3. janúar 1901, sem pó var stuttur skóladagur: „Aldamótafrí til 4 e.m.“. Miðsvetrarprófin, ásamt upplestrarfríi, röðunarfríi og mánaðarfríi taka hins vegar hátt á priðju viku, páskafrí átta daga.

Pá er vandlega bókað hvenær Geir er veikur, en pess er aldrei getið í bók Kjartans.

Einkunnir eru ekki síður óreglulegar hjá Geir en Kjartani en að jafnaði ívið fleiri, mest sextán í sömu viku og tólf viku eftir viku, en líka niður í tvær í vikum par sem hvorki getur forfalla né frídaga. Af einstökum námsgreinum vekur athygli grískan í 2. bekk. Í henni fær Geir tvær og prjár einkunnir flestar vikurnar og upp í fjórar pegar mest er. Af tuttugu manna bekk hefur kennarinn greinilega 
lagt kapp á að taka upp allmarga í hverri kennslustund. Peirra kennsluhátta hefur trúlega gætt meira í neðri bekkjunum.

Loks voru daglegar einkunnir felldar niður pegar Lærði skólinn breyttist í Hinn almenna menntaskóla (síðar Menntaskólann í Reykjavík) 1904. İ staðinn komu kennaraeinkunnir, gefnar prisvar á ári, og giltu til jafns við prófseinkunnir, nema við gagnfræðapróf (upp úr 3. bekk) og stúdentspróf. Var kennurum í sjálfsvald sett við hvað peir studdust í pessari einkunnagjöf, gátu pess vegna haldið áfram að meta til talnaeinkunnar frammistöðu hvers nemanda sem peir tóku upp. Um petta er t.d. fjallað í Fjóðviljanum 1904 par sem höfundur, vafalaust Skúli Thoroddsen, sér ekki eftir daglegu einkunnunum en telur „alveg óhafandi“ að veita kennurum svo „takmarkalaust vald yfir piltum“ sem gert sé með vægi kennaraeinkunnanna.

\section{Yfirheyrsluaðferð og skólaraðir}

Einn af rauðu práðunum í skólasögu Vesturlanda á 19. og 20. öld er hvernig vaxandi alpýðufræðsla purfti að hrista af sér venjur og viðhorf sem mótast höfðu í gömlu latínuskólunum. Par var námið ætlað fáum útvöldum til að veita peim allt aðra mótun en venjulegu fólki („menntun til aðgreiningar“ mætti kalla pað), hefðir mikils metnar, bæði um viðfangsefni og vinnulag, og kennsluhættir til pess fallnir að „gera kröfur“ fremur en að koma til móts við aðstæður og áhuga hvers og eins.

Hluti af pessari ípyngjandi arfleifð var yfirheyrsluaðferðin. Kennslustundin er pá notuð til að taka nemendur upp og hlýda peim yfir, síðan sett fyrir pað sem hlýtt verði yfir í næsta tíma. Petta kennslulag var hefðbundið í latínuskólunum (pess vegna starfsheitið „heyrari“ sem notað var um aðstoðarkennara í Skálholts- og Hólaskóla) og átti eftir að verða lífseigt, einnig á lægri skólastigum. Ég kynntist pví t.d. vel, ekki sídur í barnaskóla (frá 1956) en á gagnfræðastigi og í menntaskóla (til 1968).

Önnur arfleifð gömlu skólahefðarinnar var skólaröðin, p.e. að skipa piltum í tiltekna virðingarröð sem m.a. réð sætaskipun í skólastofunni. Slík röðun var sjálfsögð í gömlu stólskólunum, og alla 19. öld tíðkaðist að birta nafnalista skólapilta sem „skólaraðir" en ekki t.d. í stafrófsröð. Í blöðunum má af og til sjá slík yfirlit um nemendur Lærða skólans, framan af helst eins og peim var raðað eftir mánaðareinkunnum í lok nóvember, síðan eftir miðsvetrarpróf. Í lauslegri leit á timarit.is fann ég hvergi að miðað væri við röðun í lok október, pví líkast sem „mánaðareinkunnir“ hafi alla tíð verið reiknaðar á tveggja mánaða fresti. Svo seint sem í mars 1906 birtir Fjóðólfur „skólaröð í hinum almenna mentaskóla við miðsvetrarpróf“ (Skólaröð í hinum almenna mentaskóla, 1906). Sú skýring fylgir að í 1. og 2. bekk hafi blaðið sjálft purft að raða nemendum (sem par eru ekki einungis piltar heldur ein stúlka í hvorum bekk) eftir einkunnum pví að í skólanum „er nemendum alls ekki raðað öðruvísi en eftir stafrófsröð“ 'í pessum bekkjum (sem á við röðun peirra í skrám og skýrslum, en væntanlega var hætt að raða til sætis í skólastofu). Hér nær breytingin sem sagt til peirra sem hefja nám eftir nýrri reglugerð; aðferð Lærða skólans fær að fjara út með síðustu nemendum hans. Væntanlega átti pað einnig við um vitnisburðarbækurnar og peirra daglegu einkunnir.

Af og til birtu blöðin líka „skólaraðir“ annarra skóla, t.d. Möðruvallaskóla og Kvennaskólans í Reykjavík, jafnvel barnaskólans á Akureyri. Ef skýringar fylgja er raðað eftir prófseinkunnum; vorprófum við barnaskólann, inntökuprófum í Kvennaskólann. Svo t.d. í Ísafold haustið 1891 (Námsmeyjar í Reykjavíkur-kvennaskóla, 1891). Par er pó tekið fram að stúlkur „sem komu eftir að skóli var settur“ séu „settar neðstar“. Sama venja mun hafa gilt um sætaskipan í gömlu skólunum: Piltur, sem kom í skóla eftir fyrstu röðun, sat neðstur par til næst var raðað.

Nemendaskrá í stafrófsröð hef ég ekki rekist á fyrr en frá Stýrimannaskólanum í Reykjavík 1896 (Stýrimannaskólinn, 1896). Par virðist ekki gilda nein virðingarröð nemenda, hvernig sem sætaskipan hefur pá verið háttað.

Vel er hægt að kenna með yfirheyrsluaðferð án pess að daglegar einkunnir fylgi, og skólaröð eftir frammistöðu krefst ekki heldur daglegra einkunna; par duga regluleg próf. En pegar hitt var hvort 
eð er sjálfsagt, að kenna með yfirheyrslum og að raða eftir frammistöðu, pá var nærtækt að raða eftir metinni frammistöðu við yfirheyrslur, sem sagt eftir daglegum einkunnum. Pær urðu, eins og Gunnar M. Magnúss (1939, bls. 227) orðar pað „alda sem fór um erlenda skóla“ og „flæddi einnig yfir íslensku skólana“ auk pess sem hún „náði inn á önnur svið“ par sem var „mat prestsins við röðun í kirkju á fermingardegi“.

Og pví ekki? Sætaskipun í kirkju hafði löngum farið eftir mannvirðingum; gildustu bændur átt sæti í kór og svo koll af kolli fram eftir kirkjunni. Pá sagði sig sjálft að ekki væri fermingarbörnum raðað af handahófi fyrir altarinu. Nú höfðu pau gengið til „spurninga“ hjá prestinum, hann sem sagt hlýttpeim yfir barnalærdóminn. Og var pá ekki sanngjarnt, eftir jafnréttishugmyndum og einstaklingshyggju nýrrar aldar, að raða ungmennunum eftir peirra eigin frammistöðu frekar en „ætt og uppruna“?

Skólaröðun eftir formlega metinni frammistöðu var framfaramál af sama tagi. Dví óformlegra sem námsmatið var, pví óhjákvæmilegra var að pað mótaðist af mannvirðingum foreldranna. Аð raða bóndasyninum ofar en syni prófasts eða sýslumanns, pað gat kennarinn pví fremur leyft sér sem hann hafði við meira að styðjast af „hörðum gögnum“. Auðvitað væru pó hinar daglegu einkunnir engin hlutlæg og ópersónuleg mæling, ekki fremur en annað mat sem kennari leggur sjálfur á frammistöðu nemenda sinna.

\section{Og jafnvel í barnaskólum}

Pað var ekki aðeins í Lærða skólanum sem daglegar einkunnir tíðkuðust á seinni hluta 19. aldar heldur einnig í íslenskum barnaskólum. Hefur Loftur Guttormsson (2007) eftirminnilega lýst pess háttar tilhögun, sérstaklega í Barnaskóla Reykjavíkur frá 1862 og fram um aldamót. Notar Loftur par dagbækur skólans sem sýna mjög nákvæmlega hvernig háttað var skráningu einkunna.

Frá upphafi tíðkaðist að kennari gæfi börnunum einkunn fyrir frammistöðu í hverri einstakri kennslustund, og var sú aðferð bundin í reglugerð skólans frá 1866. Í skrift og reikningi, par sem allur bekkurinn vinnur að sínum verkefnum, fær hver nemandi einkunn, sömuleiðis í lestri. En í greinum par sem kennt er með yfirheyrsluaðferð fá peir einir einkunn sem kennari nær að „taka upp“ í tímanum. Var pað framan af meirihluti nemenda, jafnvel pó bekkjarstærð væri um og yfir 30. Er pví ljóst að kennarar hafa lagt kapp á að hlýða sem flestum nemendum yfir hverju sinni og gefið nákvæma einkunn fyrir yfirheyrslu sem stóð aðeins örfáar mínútur. Hefur pá reynt á að barnið gæti pulið utanbókar sinn skammt af lexíu dagsins, fremur en að pað væri svo mjög samræðuhæft um inntak lexíunnar.

Rétt eins og í Lærða skólanum var pessi einkunnaflaumur færður í „vitnisburðarbók“ sem börnin áttu að sýna foreldrum sínum um hverja helgi. Mánaðarlega var reiknuð heildareinkunn og eftir henni raðað til sætis í bekknum, pau hæstu fremst (eða „efst“ eins og pað hét), pau lægstu aftast. Var ætlast til að petta hleypti börnunum kappi í kinn svo að pau legðu sig fram um að verja sæti sitt í bekknum eða helst „vinna sig upp“ í enn virðulegri sess.

Svona var ekki aðeins farið að í Reykjavík. „Daglegar einkunnir eru gefnar í langflestum skólanna“ segir Guðmundur Finnbogason (1905, bls. 51) um athugun sína á kennslu í föstum barnaskólum landsins veturinn 1903-1904, síðasta starfsár Lærða skólans.

\section{Dependerað af dönskum}

Íslenska skólakerfið var að sjálfsögðu mótað með hliðsjón af pví danska. Pað kemur pví ekki á óvart að í Danmörku hafði dagleg einkunnagjöf tíðkast bæði á barna- og framhaldsskólastigi. Íslenskir barnaskólar gátu pví sótt sína fyrirmynd til sama skólastigs í Danmörku, ekki síður en til Lærða skólans. 
Noregur var hér á sama báti og Ísland. Prátt fyrir aðskilnað hans frá danska ríkinu 1814 var skólakerfið og skólahefðin af dönskum rótum runnin. Pví er athyglisvert að sjá frásögn norsks skólamanns sem 1888 hafði heimsótt framhaldsskóla, bæði í Kaupmannahöfn og Berlín, til að kynna sér kennsluhætti í raungreinum, einkum stærðfræði. Í Kaupmannahöfn lýsir hann mest námsefninu, en pegar til Berlínar kom er pað sjálf kennslan sem kemur gestinum ánægjulega á óvart (Hamilton, 1890, bls. 90):

Hinar sálardrepandi yfirheyrslur, par sem daglegar einkunnir eru vegnar og mældar og sem hjá okkur taka iðulega megnið af kennslustundinni og eiga drýgstan pátt í að gera kennsluna purra og sundurbútaða, pær voru prússnesku skólarnir lausir við.

Fyrir petta hafði hann ekki séð ástæðu til að hrósa dönsku skólunum, sem hafa pá verið undir sömu sök seldir og peir norsku. Að yfirheyrslur vegna daglegra einkunna taki „iðulega megnið af kennslustundinni“", pað lýsir kennsluháttum sem voru a.m.k. ekki skárri en í Lærða skólanum í Reykjavík.

Danskir gagnfræðaskólar, „mellem- og realskoler“, höfðu líka notað daglega einkunnagjöf. Eftir 1890 var hún orðin í tilfinnanlegu ósamræmi við kennsluhættina par sem kennarar vildu tala til bekkjarins frekar en yfirheyra nemendur einn og einn. Pá voru pað foreldrar sem vildu halda í gamla lagið. Allt fram til 1916 var enn algengast að nota daglegar einkunnir og vikulegan vitnisburð til foreldra. Færri skólar gáfu mánaðarlegan vitnisburð, hvað pá ársfjórðungslegan (Haue, 2010, bls. 346). Рað var svo 1920 sem bannað var að gefa einkunn fyrir frammistöðu pegar nemendur voru teknir upp; aðeins mætti gefa einkunnir fyrir skrifleg verkefni (Haue, 2010, bls. 347).

Í dönskum barnaskólum tíðkuðust líka daglegar einkunnir, misjafnt pó hve fast peim var fylgt fram, enda hafði sjálft kirkju- og kennslumálaráðuneytið svo snemma sem 1882 hvatt til hófsemi í peim efnum. Dagleg einkunnagjöf var pó a.m.k. sjálfsögð í einkareknum „forberedelsesskoler“, p.e. skólum sem einkum áttu að búa nemendur undir nám í lærðum skólum (Gjerløff og Jacobsen, 2014, einkum bls. 62). Er pví líkast sem íslensku barnaskólarnir hafi helst samið sig að háttum peirra. Minna fer fyrir áhrifum frá menntahugsjón lýðskólahreyfingarinnar, sem brást við öfgum latínuskólahefðarinnar með pví að hafna helst öllum prófum, einkunnum og yfirheyrslum. Hugmyndir hennar höfðu vissulega sín áhrif á Íslandi (Jón Torfi Jónasson, 1999), en pau birtast fyrst á framhaldsskólastiginu og í óformlegri fræðslustarfsemi, ekki í hinum hefðbundnu barnaskólum.

\section{Barnaskólar síðasta vígið}

Lítum nánar á fyrrnefndan vitnisburð Guðmundar Finnbogasonar (1905, bls. 51) um barnaskólana 1903-1904:

Daglegar einkunnir eru gefnar í langflestum skólanna, en mörgum kennurunum er illa við pær. Aftur á móti halda margir foreldrar fast við pær, mest fyrir metnaðar sakir. Ættu pær að minni hyggju að hverfa sem fyrst úr öllum skólum, pví pær eru einn hyrningarsteinninn undir pululærdóminum. Á stöku stað hafa daglegar einkunnir verið lagðar niður, og er pá gefin ein einkunn í hverri grein á viku hverri eða mánuði og börnunum raðað eftir pví.

Petta átti við um föstu skólana eina, sem búið var að stofna á helstu péttbýlisstöðum. Peir voru reyndar ekki dæmigerðir fyrir íslenska barnafræðslu. Meira kvað að farskólum sveitanna, og ekki síður eftir að fræðsluskylda var leidd í lög 1907; henni var víðast hvar mætt með farskólahaldi. Námsmat farskólanna, fyrir utan hin lögboðnu próf, hefur naumast verið með sama sniði og í föstu skólunum. Um pað eru heimildir annars ekki auðfundnar, a.m.k. ekki í peim formlegu gögnum sem fræðsluskýrslur byggjast á.

Guðmundur er hiklaust andvígur daglegum einkunnum, eins og hann segir að margir kennarar séu líka. Enda hlutu sæmilega upplýstir skólamenn, pegar hér var komið sögu, að aðhyllast aðrar kennsluaðferðir en einhliða yfirheyrslur, aðferðir sem ekki var auðvelt að samrýma sífelldri 
einkunnagjöf. Рað eru hins vegar foreldrarnir - rétt eins og í dönsku gagnfræðaskólunum - sem að sögn Guðmundar halda í gamla einkunnakerfið. Ekki allir foreldrar, en „margir“, og pá „fyrir metnaðar sakir". Má ætla að par eigi ekki síst í hlut peir foreldrar sem nokkuð áttu undir sér, fólk sem gjarna vildi sjá börn sín skara fram úr í námi og ætlaðist til skólinn léti pað ganga eftir.

Pær vikulegu eða mánaðarlegu einkunnir, sem „á stöku stað“ er farið að nota í stað hinna daglegu, hljóta að vera kennaraeinkunnir, líkar peim sem brátt voru teknar upp í Menntaskólanum. Sá er pó munur á að í Menntaskólanum var jafnframt horfið frá röðun nemenda eftir einkunnum, en í barnaskólunum er, að sögn Guðmundar, „börnunum raðað eftir“ pessum kennaraeinkunnum. Ef pað er metnaður foreldra sem ræður, pá er röðunin aðalatriði, fremur hægt að sætta sig við breytingar á einkunnagjöfinni.

Nú var raunar kominn sá tími að jafnvel metnaðarfyllstu foreldrar urðu að sætta sig við býsna hratt undanhald hins hefðbundna símats í íslenskum barnaskólum. Pá sögu hefur Loftur Guttormsson rakið, í grein sinni sem fyrr er nefnd, fram til setningar hinna nýju fræðslulaga 1907. Er vafalaust rétt, eins og hann bendir á, að par hafi Menntaskólinn verið áhrifamikil fyrirmynd.

Jafnvel pótt dagleg einkunnagjöf í barnaskólum styddist ekki lengur við fyrirmynd Lærða skólans, og hversu hastarlega hún braut í bága við viðtekna kennslufræði, pá virðist hún engu að síður hafa átt sína málsvara, og pað fram yfir lagabreytinguna 1907.

Um pað hef ég að vísu ekki nema óbeina heimild; forsîðugrein í gamla Skólablaðinu, málgagni Hins íslenska kennarafélags, 15. september 1908. Fyrirsögn: „Daglegar einkunnir“. Höfundur er ekki nafngreindur, en vafalaust er hann enginn annar en ritstjórinn, Jón Pórarinsson fræðslumálastjóri.

Jón segir fyrst að pennan „skólasið“ pekki „peir sem gengið hafa í skóla fyrir nokkrum áratugum og jafnvel fyrir skemmri tíma“. Hann tilgreinir hér ekki einn skóla öðrum fremur og lýsing hans á aðferðinni er öll miðuð við barnaskóla. Bersýnilega hafði hún verið alsiða í peim fáu barnaskólum sem til voru á Íslandi „nokkrum áratugum“ fyrir 1908. Og í sumum barnaskólum hlýtur hún að tíðkast enn; pað eru peir sem fræðslumálastjóri vill telja hughvarf með greininni.

Jón lýsir yfirheyrsluaðferðinni pannig að börn séu „tekin upp“ til að athuga hvort pau hafi „lært (utanbókar) pað sem peim hafði verið sett fyrir“. Kennarinn hafi pá „lítið að gera annað en pað að hlusta á puluna hjá barninu - og gefa vitnisburð, einkunn, fyrir frammistöðuna“. Petta sé fært í sérstaka bók hjá hverju barni. Pað á svo „um hverja helgi að sýna vandamönnum sínum vitnisburðarbókina og peir að skrifa nafn sitt í hana til sannindamerkis um að peir hafi séð bókina“. Рað sem börnin taki eftir og hafi áhuga á sé pó ekki svo mjög einkunnirnar sjálfar heldur „röðunin. Eftir meðaltali allra daglegra einkunna er börnunum raðað um hver mánaðamót“ og sé peim keppikefli að lenda „ofarlega í röðinni“.

Kennarinn á að „gefa vitnisburð daglega og í hverri kennslustund“. En í 50 mínútna kennslustund nær hann ekki, að mati Jóns, að yfirheyra meira en sex eða sjö börn, af jafnvel 30 (hann reiknar með aldursblöndun og fjölmennum bekkjum). Hvert barn veit nokkurn veginn hvenær röðin kemur að pví næst og getur hagað heimanámi eftir pví. Pannig getur pað tryggt sér glæsilegan vitnisburð sem „dregur [...] foreldra og vandamenn á tálar, og gefur börnunum sjálfum einnig rangar hugmyndir um sig“.

Parna hefur eitthvað breyst frá pví sem Loftur Guttormsson sá í gögnum frá 19. öld. Pá höfðu nemendur verið teknir upp eins og á færibandi, örfáar mínútur hver. Nú gengur pað hægar. Enda „er skólakennsla nokkuð orðin á annan veg“ en pá. Kennarinn setur enn fyrir, „en vinna hans er nú aðallega fólgin í pví að kenna, ekki hlýða yfir“.

Yfirheyrsluaðferðin er, að áliti Jóns, „ekki kennsla heldur eins konar próf“, alveg andstæð hinum rétta tilgangi heimanáms par sem börnum er sett fyrir efni „sem pau eiga að [...] kynna sér svo vel að pau geti fest pað betur í minni sem kennarinn hefir að segja um sama efni í kennslustundunum næsta dag“. En pegar „aðalvinna kennarans er fólgin í pví að kenna, tala við börnin og fræða pau“ fremur 
en „hlýða peim yfir eða prófa“, „hvernig getur pá verið vit í að gefa einkunnir í peim kennslustundum par sem um ekkert slíkt er að ræða?“”

Jón beinir sem sagt máli sínu til barnaskóla par sem kennsluaðferðin hefur breyst en krafa gerð engu að síður um sífellda einkunnagjöf, vitnisburðarbók um hverja helgi og mánaðarlega röðun eftir frammistöðu. Í pað fer „talsverður tími“ sem „flestir kennarar“ finna að væri „til annars betur varið“. Peir halda pá yfirheyrslunum í lágmarki til að geta kennt sem mest í alvöru. Ef barnið hefur sinnu á að læra fyrir pau fáu skipti pegar pað er tekið upp verður bókin „full af glæsilegum einkunnum“, vitnisburðinum sem Jón segir að blekki foreldra og skekki sjálfsmynd barnanna.

Árið 1908 er dagleg einkunnagjöf sem sagt nógu mikið vandamál í íslenskum barnaskólum til pess að nýskipaður fræðslumálastjóri sjái ástæðu til að andæfa henni af fullum punga. Hann var pá líka að undirbúa reglur um próf í barnaskólunum sem gefnar voru út sî̉ar á árinu. Par er skólunum í sjálfsvald sett hvort peir beita formlegu símati, en pá gert ráð fyrir aðeins einni tilhögun pess: „Ef mánaðareinkunnir hafa verið gefnar" eiga pær að gilda að hálfu á móti einkunn á vorprófi (Reglur um barnapróf, 1910, bls. 32).

\section{Sögulok?}

Pannig má segja að sögu daglegrar einkunnagjafar í íslensku skólakerfi ljúki skólaárið 1908-1909, með nýnefndri reglugerð barnaskólanna og með útskrift síðasta árgangsins sem hóf nám í Lærða skólanum fyrir 1904. İ öðrum skólum hefur hún væntanlega verið úr sögunni pá pegar. Að pví leyti sem „símat" var viðhaft áfram færðist pað í form kennaraeinkunna sem gefnar voru í mesta lagi mánaðarlega.

Pá var undir kennaranum komið á hverju hann byggði pær einkunnir. Hjá sumum hefur daglega einkunnagöffin væntanlega aðeins færst „undir yfirborðið“. Peir hafa haldið áfram að nota kennslustundirnar að mestu til að „taka upp“ nemendur, svo marga sem peir komust yfir, skráð frammistöðu peirra í tölum og reiknað einkunnir út frá pví. Kennslustundin var pá í raun „munnlegt skyndipróf“ rétt eins og verið hafði. Hve hægt og seint sú aðferð fjaraði út í raun, sérstaklega í framhaldsskólunum, pað er önnur saga sem ekki verður reynt að rekja hér.

\section{Teach or Check? Daily Assessment in Icelandic Schools in Late 19th/Early 20th Century}

The immediate object of the present study is a document: the log book of a student at the Reykjavík Latin School (Lærði skólinn) 1885-1886. The booklet, containing inter alia numerical grades for the student's performance every single time he was selected for individual questioning by a teacher, shows in detail the application of traditional "daily assessment" which tended to restrict the role of the teacher to evaluation rather than instruction. A part of the system was the ordering of students by performance, revised every month or two, visibly reflected in the seating arrangement in the classroom.

This style of daily assessment at the Latin School was controversial and subject to some variation, yet basically unaltered until abolished in 1904 as part of a radical overhaul of the school, thenceforth known as the Reykjavík Grammar School.

Said log book shows a somewhat flexible application of the system of daily assessment. A "monthly" summary is calculated only three times over the school year; "weekly" written compositions (or translations) are assessed about every other week; and the frequency of questioning varies between subjects, indicating that some classes - particularly in Icelandic language and literature - were devoted to instruction rather than evaluation. 
The ordering of students by performance, reflected in the classroom seating arrangement, was common in other schools, both elementary and secondary, based either on daily assessment or periodical examinations. Alphabetical student registers are rarely seen until introduced in the Grammar School as of 1904. Even the Lutheran state church in its rite of confirmation reflected the practice of the schools, with the confirmands receiving their first communion in the pecking order established by their mastery of the catechism.

While rural Iceland retained a system of traditional home schooling, increasingly assisted by itinerant teachers, permanent elementary schools were established in the towns and larger villages. These mainly adopted a system of daily assessment, closely reflecting the practice of the Latin School. While teachers increasingly preferred class discussion to individual questioning, and thus found daily assessment at odds with their teaching style, conservative parents opposed its abolition. Not until $1908 \mathrm{did}$ a newly established Education Authority take steps to replace it in a similar way as had been done in the grammar School in 1904.

Iceland was a Danish dependency, with Denmark as its "window on the world" and Danish practices as its natural models. It therefore comes as no surprise that the practice of daily assessment was much the same in Danish schools as in Icelandic ones, with the same protracted struggle to have it abolished.

\section{Um höfund}

Helgi Skúli Kjartansson (helgisk@hi.is) er sagnfræðingur, fyrrverandi prófessor við Menntavísindasvið Háskóla Îslands (áður Kennaraháskóla Îslands). Hann hefur í kennslu og rannsóknum m.a. fjallað um íslenska skólasögu, einkum á 20. öld. Helgi er afkomandi sr. Kjartans Helgasonar frá Birtingaholti.

\section{About the author}

Helgi Skúli Kjartansson (helgisk@hi.is) is an Icelandic historian, professor emeritus at the University of Iceland (School of Education). He has published widely on the history of Icelandic education, mainly contemporary history.

\section{Heimildir}

Ásmundur Guðmundsson. (1946). Ærslaveturinn í 2. bekk. Í Ármann Kristinsson og Friðrik Sigurbjörnsson (ritstjórar), Minningar úr menntaskóla (bls. 236-242). Reykjavík: Ármann Kristinsson.

Finnur Jónsson. (1883). Um hinn lærða skóla á Íslandi. Andvari, 9, bls. 97-135.

Gjerløff, A. K. og Jacobsen, A. F. (2014). Da skolen blev sat i system. 1850-1920. Dansk skolehistorie (III. bindi). Aarhus: Aarhus Universitetsforlag.

Guðmundur Finnbogason. (1905). Skýrsla um fraðslu barna og unglinga veturinn 1903-1904. Reykjavík: [án útgefanda].

Gunnar M. Magnúss. (1939). Saga alpýðufraðslunnar á Íslandi. Reykjavík: Samband íslenskra barnakennara.

Hamilton, Wm. (1890). Indberetning fra adjunkt Wm. Hamilton om en i 1888 foretagen reise til Kjøbenhavn og Berlin for að studere realfagenes metodik, særlig den forberedende matematikundervisning (seinni hluti). Universitets- og skole-annaler. Ny rakke, 5(6-8), 81-118.

Haue, H. (2010). Almendannelse og nyttige kundskaber. Skoler, eksaminer, censur og karaktergivning 17871923. Í Christian Larsen (ritstjóri), Realskolen gennem 200 år, I - Kundskaber og erhvervsforberedelse (bls. 323-350). Kaupmannahöfn: Danmarks Privatskoleforening. 
Jón Torfi Jónasson. (1999). Lýðskólar á Íslandi í byrjun 20. aldar. Í Helgi Skúli Kjartansson o.fl. (ritstjórar), Steinar i vörðu til heiðurs Puríði J. Kristjánsdóttur sjötugri (bls. 107-134). Reykjavík: Rannsóknarstofnun Kennaraháskóla Íslands.

Jón Ólafsson. (1946). Skólalíf í Reykjavík um og eftir 1863. Í Ármann Kristinsson og Friðrik Sigurbjörnsson (ritstjórar), Minningar úr menntaskóla (bls. 27-43). Reykjavík: Ármann Kristinsson.

[Jón Pórarinsson]. (1908, 15. september). Daglegar einkunnir. Skólablaðið, 2(17), bls. 65-66.

Kristinn Daníelsson. (1946). Hinn almenni menntaskóli. Lærði skólinn - Latínuskólinn. Nokkrar minningar. Í Ármann Kristinsson og Friðrik Sigurbjörnsson (ritstjórar), Minningar úr menntaskóla (bls. 51-63). Reykjavík: Ármann Kristinsson.

Loftur Guttormsson. (2007). Daglegar einkunnagjafir. Í Benedikt Eypórsson og Hrafnkell Lárusson (ritstjórar), Priðja íslenska sögupingið 18.-21. maí 2006. Ráðstefnurit (bls. 287-297). Reykjavík: Sagnfræðingafélag Íslands.

Lærisveinar hins lærða skóla. (1882, 7. janúar). Norðanfari, 21(7-8), bls. 14-15.

Matthías Jochumsson. (1946). Skólaár mín. Í Ármann Kristinsson og Friðrik Sigurbjörnsson (ritstjórar), Minningar úr menntaskóla, (bls. 21-25). Reykjavík: Ármann Kristinsson.

Námsmeyjar í Reykjavíkur-kvennaskóla veturinn 1892-1891. (1891, 11. nóvember). Ísafold, 18(90), bls. 359.

Reglur um barnapróf (7. desember 1908). (1910). Í Lög og fyrirskipanir um fraðslu barna og unglinga, (bls. 28-32). Reykjavík: [án útgefanda].

Skólaröð í hinum almenna mentaskóla við miðsvetrarpróf 1906. (1906, 9. mars). Pjóðólfur, 58(10), bls. 38.

[Skúli Thoroddsen]. (1904, 24. október). Nýja skólareglugjörðin. Pjóðviljinn, 18(42), bls. 165.

Skýrsla um hinn larða skóla i Reykjavík. Skóla-árið 1885-86. (1886). Reykjavík: [án útgefanda].

Stýrimannaskólinn. (1896, 21. nóvember). Ísafold, 23(80), bls. 318.

Helgi Skúli Kjartansson. (2020).

Dagleg einkunnagjöf í íslenskum skólum

Netla - Veftímarit um uppeldi og menntun. Menntavísindasvið Háskóla Íslands.

Sótt af http://netla.hi.is/greinar/2020/alm/13

DOI: https://doi.org/10.24270/netla.2020.13

\footnotetext{
${ }^{1}$ Sú athugun er ekki svo vísindalega gerð, eða sett fram með svo fræðimannlegum hætti, að hæfi ritrýndri birtingu. Ég var pó svo heppinn að ritstjórar sendu greinina engu að síður til tveggja ritrýna, og pakka ég peim fjölda gagnlegra ábendinga.

${ }^{2}$ Hér og framvegis er stuðst við Skýrslu um hinn lærða skóla (1886), bls. 4 (nemendur í skólaröð „við hina fyrstu sætaskipun 2. dag desembermánaðar“), 6 (námsgreinar og vikustundir), 7 (kennarar), 8-10 (námsefni), 30 (umsjónarmenn), 32-33 (stúdentspróf, lokaeinkunnir).

3 Samsvarar daily grading á ensku sem pó er notað í víðari merkingu um símat, ekki síst fyrir ástundun og hegðun.

4 Ég pakka Gylfa Zoëga fyrir aðgang að pessum gögnum.

${ }^{5}$ Loftur Guttormsson, 2007, bls. 288: Einkunn skráð „hvern pann dag sem [...] barn er reynt í [...] námsgrein eða látið hafa hana um hönd.“ Barnið er pá „reynt“ (p.e. prófað) í námsgrein pegar pað er tekið upp, en „hefur hana um hönd“ pegar allur bekkurinn vinnur verkefni, eins og í skrift og reikningi.

${ }^{6}$ Pýðing greinarhöfundar. „Det aandsfortærende forhør með udveining og udmaaling af daglige karakterer, som hjemme hos os ofte indtager største delen af timen og mere end noget andet bidrager til að gjøre undervisningen tør og udstykket, det var man i preussiske skoler fri for."

${ }^{7}$ Afnema „den daglige Karaktergivning for de mundtlige Præstationer“.

8 Jón hafði verið skólastjóri Flensborgarskólans, en kennarar par hófu útgáfu Skólablaðsins 1907. Jón tók við ritstjórn pess sumarið 1908, um sama leyti og hann var skipaður í hið nýja embætti fræðslumálastjóra. Litlu síðar færðist útgáfan í hendur Hins íslenska kennarafélags par sem Jón var einnig í forustu.

9 Orðið „barnapróf“, sem síðar var haft um lokapróf barnastigsins, er parna samheiti um vorpróf barnaskólanna, jafnt árspróf sem fullnaðarpróf.
} 